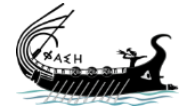

journal.phaselis.org
PHASELIS

Disiplinlerarası Akdeniz Araştırmaları Dergisi

Journal of Interdisciplinary Mediterranean Studies

Issue IV (2018)

Phaselis' New Endemic Host:

(Alyssum macropodum Boiss. \& Balansa)

(Antalya, Turkey)

Phaselis' New Endemic Host:

(Alyssum macropodum Boiss. \& Balansa)

(Antalya, Turkey)

Fatma AKDENiz - ilker ÇiNBiLGEL - Hacer BAKIR SERT

open 2 access journals

The entire contents of this journal, Phaselis: Journal of Interdisciplinary Mediterranean Studies, is open to users and it is an 'open access' journal. Users are able to read the full texts, to download, to copy, print and distribute without obtaining the permission of the editor and author(s). However, all references to the articles published in the e-journal Phaselis are to indicate through reference the source of the citation from this journal.

Phaselis: Journal of Interdisciplinary Mediterranean Studies is a peer-reviewed journal and the articles which have had their peer reviewing process completed will be published on the web-site (journal.phaselis.org) in the year of the journal's issue (e.g. Issue III: JanuaryDecember 2017). At the end of December 2016 the year's issue is completed and Volume IV: January-December 2018 will begin.

Responsibility for the articles published in this journal remains with the authors.

Citation F. Akdeniz, İ. Çinbingel - H. Bakır Sert, "Phaselis' New Endemic Host: (Alyssum macropodum Boiss. \& Balansa) (Antalya, Turkey)". Phaselis IV (2018) 85-88. http://dx.doi.org/10.18367/Pha.18006

Received Date: 12.02.2018 | Acceptance Date: 09.03.2018

Online Publication Date: 15.03.2018

Editing Phaselis Research Project

www.phaselis.org 


\title{
Phaselis' New Endemic Host: (Alyssum macropodum Boiss. \& Balansa) (Antalya, Turkey)
}

\author{
Phaselis'te Yeni Bir Endemik Konukçu: (Alyssum macropodum Boiss. \& Balansa) \\ (Antalya, Türkiye)
}

\author{
Fatma AKDENiz ${ }^{*}$ ilker ÇiNBILGEL ${ }^{* *}$ Hacer BAKIR SERT ${ }^{* * *}$
}

\begin{abstract}
Phaselis was an ancient Greek and Roman city on the coast of Lycia. Its ruins are located north of the modern town Tekirova in the Kemer district of Antalya Province in Turkey. It lies between the Taurus Mountains and the forests of Olympos National Park. During a study in Phaselis antique city, the fungal species Erysiphe cruciferarum Opiz ex L. Junell is determined on an endemic plant species Alyssum macropodum Boiss. \& Balansa. E. cruciferarum is a powdery fungus species and identified on this endemic host plant for the first time in Turkey. The study present, description, macro-microscopical characteristics features of Erysiphe cruciferarum on Alyssum macropodum were given.
\end{abstract}

Keywords: Phaselis, Microfungi, Alyssum macropodum, Turkey

Öz: Lykia kıyısında antik bir Hellen ve Roma kenti olan Phaselis harabeleri hâlihazırda Antalya ili Kemer ilçesinde, Tekirova'nın kuzeyinde; Toros Dağları ile Olympos Milli Parkı ormanları arasındadır. Phaselis'te yapılan bir araştırma sırasında, bir mantar türü olan Erysiphe cruciferarum Opiz ex L. Junell, endemik bir bitki türü Alyssum macropodum Boiss \& Balansa üzerinde tespit edildi. Bir külleme mantarı türü olan $E$. cruciferarum'un, bu endemik konak bitki türü üzerindeki kaydı Türkiye'de ilk olup yapılan çalışmada, $A$. macropodum üzerinde $E$. cruciferarum'un tanımlaması, makro-mikroskobik özellikleri verilmiştir.

Anahtar sözcükler: Phaselis, Mikrofungi, Alyssum macropodum, Türkiye

\section{Introduction}

Fungi are an important group of plant pathogens. The vast majority of fungi receive some of their nutrients or the whole plant from their host plants. Mostly of all the major plants diseases are caused by fungi. But very few of the known fungi can colonize the living plants. Commonly crop and wild plants are infected by powdery mildews, which in general are hostspecific ${ }^{1}$.

Turkey has a very diverse mycoflora and flora many studies have been carried out concerning. The first and most important control the fungal diseases in a country is to study the mycoflora and determine their hosts ${ }^{2}$.

\footnotetext{
* Akdeniz University, Institute of Science, Antalya, fatma_akdeniz027@hotmail.com

** Asst. Assoc. Dr., Akdeniz University, Manavgat Tourism Faculty, Manavgat, Antalya, icinbilgel@akdeniz.edu.tr

*** Prof. Dr. Akdeniz University, Manavgat Tourism Faculty, Manavgat, Antalya, hacersert@akdeniz.edu.tr

1 Knogge 1996; Deacon 2006.

2 Farr et al. 2004; Sert et al. 2006.
} 
In this study Erysiphe cruciferarum Opiz ex L. Junell is identified on an endemic plant in Phaselis Ancient city, Alyssum macropodum Boiss. \& Balansa.

The powdery fungus is identified on this host for the first time in Turkey ${ }^{3}$.
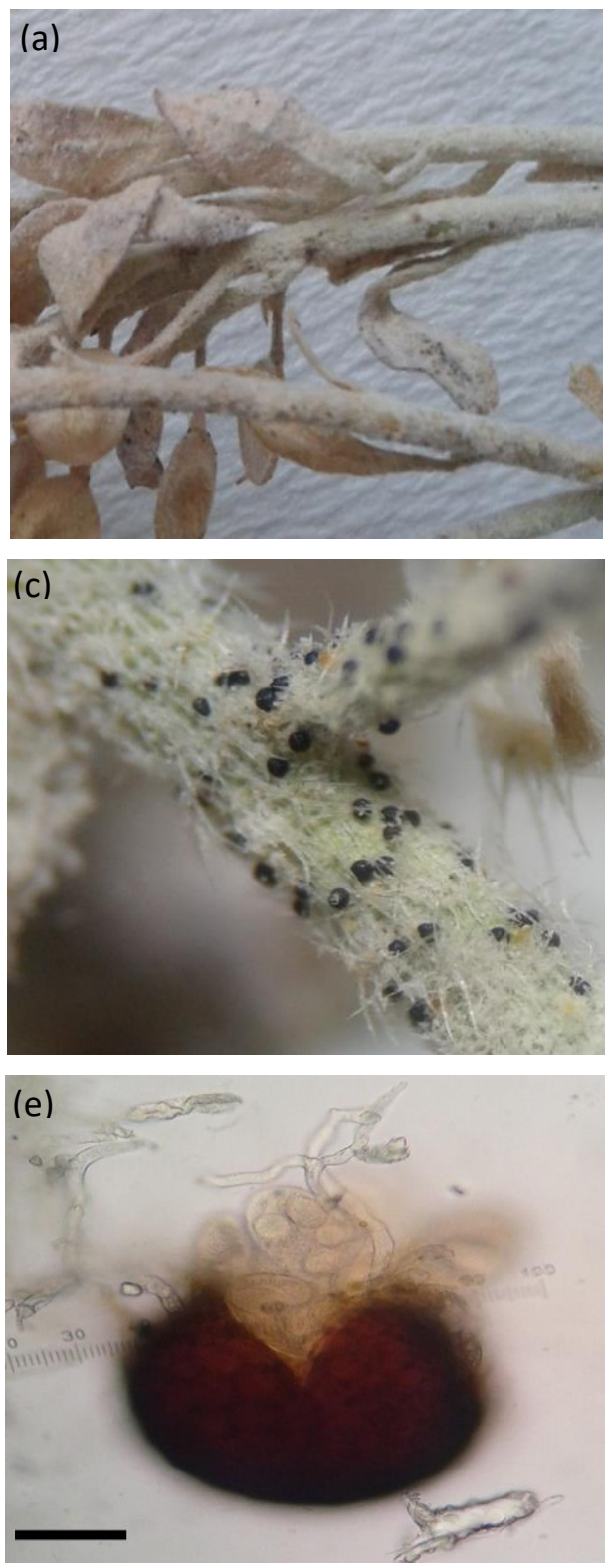
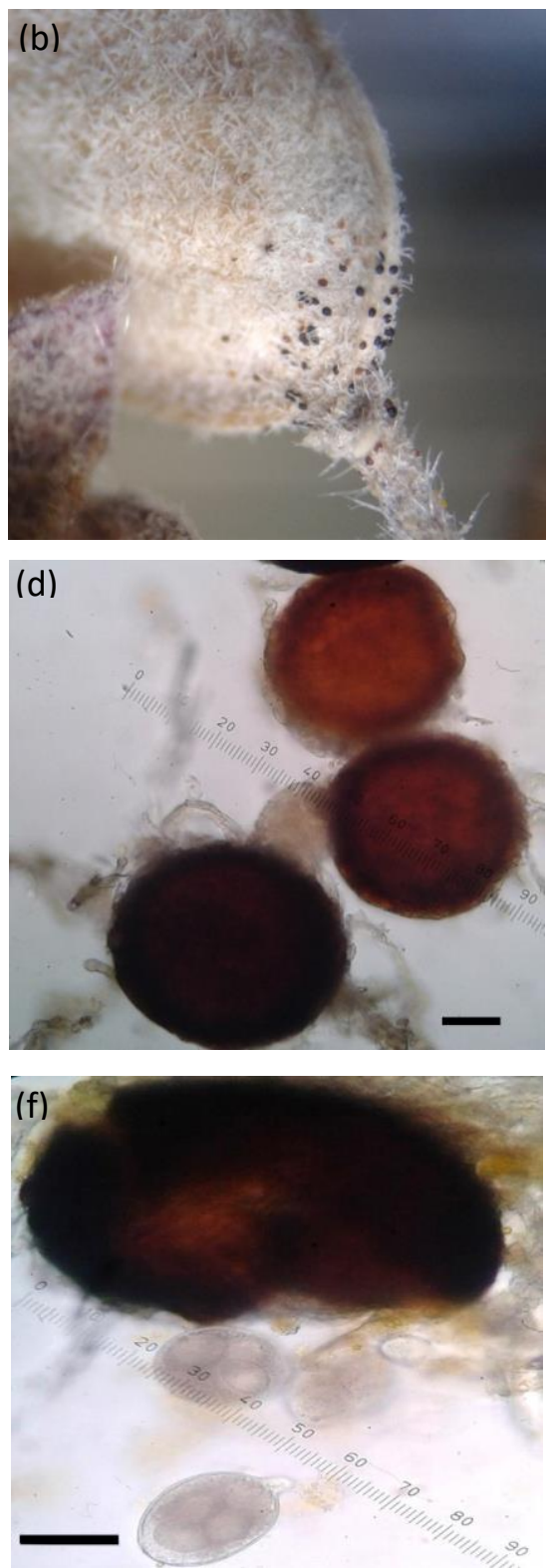

Figure 1: Erysiphe cruciferarum on Alyssum macropodum; (a, b, c) Stereo microscopic views: (a) Mycelium on leaves and stem (b, c) Chasmothecia; (d, e, f) Light microscopic views: (d) Chasmothecia, (e, f) chasmothecia and asci

(Bars: d: $10 \mu \mathrm{m}$, e: $20 \mu \mathrm{m}$ f: $20 \mu \mathrm{m}$.)

3 Phaselis antique city is located in the Antalya province and is mainly in the Mediterranean phytogeo-graphical region. It was chosen as a research area, because its climatic conditions (especially high humidity) and plant distributions are very suitable for the growth of microfungi. 


\section{Material and Methods}

Phaselis ancient city and surrounding plant species specimens were collected and recorded during spring and summer (2016-2017) throughout the research period. Typical symptoms of powdery mildew are observed in various parts of the plant such as fruit and leaves. The preparations were examined microscopically and the mean spores morphologies were compared with information in the literature Branderburger (1985), Braun (1995), Braun and Cook (2012), Host plants were identified with the help of Flora of Turkey Davis (1965-1985), Davis et al. (1988), Güner et al. (2000, 2012) Flora of Antalya City (Göktürk 1994). The specimens are preserved at the Akdeniz University, Manavgat Vocational School Laboratory (Antalya, Turkey).

\section{Descriptions of Taxa}

Erysiphe cruciferarum is identified on a host plant nominated Alyssum macropodum (Brassicaceae). A. macropodum is an endemic plant in one of the important antique city of Turkey, Phaselis. This powdery fungus is identified on this host for the first time in Turkey.

\section{Erysiphaceae}

Erysiphe cruciferarum Opiz ex L. Junell

Mycelium white, on stems, fruits and on both surfaces of leaves, effuse, amphigenous and persistent. Hyphal appressoria almost unlobed and solitary. Conidiophores straight, 35-75 $\mu \mathrm{m}$ long, forming conidia singly, conidia cylindrical, ellipsoid-doliiform, 12-20×7-15 $\mu \mathrm{m}$. Chasmothecia scattered, 60-125 $\mu \mathrm{m}$, appendages in lower half of the ascomata, 0.25-3 times, 0.5-2 times the chasmothecial diam. (about 25-230 um long), septate, walls thin, hyaline yellowish to brownish in the lower half, pale, asci, (3-)4-8(-10), almost short-stalked, obovoid, clavatesaccate, (2-)4-6(-8) spores; ascospores elipsoid-obovoid, 5-8×9-15 $\mu \mathrm{m}$, colourless (Fig. 1).

Specimen examined: on living stems, fruits and leaves of Alyssum macropodum Boiss. \& Balansa, (Brassicaceae) Turkey, Antalya, Phaselis Ancient City, 2016, F.A. 3013b. 
Braun 1995

Braun - Cook 2012

Davis 1965-1985

Davis et al. 1988

Deacon 2006

Farr et al. 2004

Göktürk 1994

Güneş - Özhatay 2000

Güner et al. 2000

Güner et al. 2012

Knogge 1996

Sert et al. 2006

\section{BIBLIYOGRAFYA}

U. Braun, The Powdery Mildews (Erysiphales) of Europe. Gustav Fischer Verlag 1995.

U. Braun - R. T. A. Cook, Taxonomic Manual of the Erysiphales (Powdery Mildews). Cbs Biodiversity Series. Cbs-Khaw Fungal Biodiversity Centre, Utrecht, The Netherlands 2012.

P. H. Davis, Flora of Turkey and the East Aegean Islands. Vol. I-X. Edinburgh - UK 1965-1985.

P. H. Davis, R. R. Mill - K. Tan, Flora of Turkey and the East Aegean Islands. Vol. 10. Suppl. 1, 324-326. Edinburgh 1988.

J. Deacon, Fungal Biology. Malden, MA, USA 2006.

D. F. Farr, A. Y. Rossman, M. E. Palm - E. B. Mc Cray, "Fungal Databases". Beltsville, MD, USA, Systematic Botany \& Mycology Laboratory, Agricultural Research Service, USDA 2004. http://nt.ars-grin.gov/fungaldatabases.

R. S. Göktürk, Antalya Şehir Florası Üzerinde Bir Araştırma. Yayımlanmamış Yüksek Lisans Tezi, Akdeniz Üniversitesi. Antalya 1994.

F. Güneş - N. Özhatay, "Lathyrus". Eds. A. Güner, N. Özhatay, T. Ekim, K. H. C. Başer, Flora of Turkey and the East Aegean Islands, Suppl. 2, Vol. 11, Edinburgh (2000) 92-94.

A. Güner, N. Özhatay, T. Ekim - K. H. C. Baser, Flora of Turkey and the East Aegean Islands. Vol. 11. Edinburgh 2000.

A. Güner, S. Aslan, T. Ekim, M. Vural - M. T. Babac (eds.), A Check List of the Flora of Turkey (Vascular Plants). Nezahat Gökyiğit Botanik Bahçesi ve Flora Araştırmaları Derneği Yayını. İstanbul 2012.

W. Knogge, "Fungal Infection of Plants". The Plant Cell 8 (1996) 1711-1722.

H. B. Sert, H. Sümbül - K. Sterflinger, "Occurrence of powdery mildews on new hosts in Turkey". Phytoparasitica 34 (2006) 474-476. 